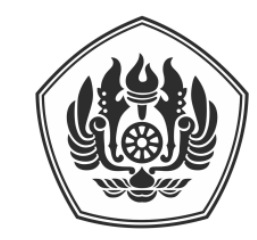

Padjadjaran Journal of International Law

ISSN: 2549-2152, EISSN: 2549-1296

Volume 3, Number 1, January 2019

\title{
Indonesia-Malaysia Maritime Boundaries Delimitation: A Retrospective
}

\section{Eddy Pratomo*}

\begin{abstract}
"Good fences make good neighbors." But how long should one build those fences with its neighbor? Boundary delimitation has always been an eye-catching issue in international law and international relations. Sometimes it can take up for many years. States tend to be very cautious in delimiting its boundary because once it is agreed, it cannot be changed anymore. Indonesia-Malaysia maritime boundary is not an exception. These two relatively young nations have negotiated their maritime boundaries since the 1960's. More than fifty years later, maritime boundary segments still remain to be settled. But where does it stand now? This article will highlight a number of important issues of the Indonesian-Malaysian maritime boundaries delimitation, the latest development, and the way forward on where these two nations will proceed.
\end{abstract}

Keywords: Archipelagic Baseline, Boundary Agreement, Continental Shelf, Exclusive Economic Zone, Maritime Delimitation

\section{Delimitasi Batas Maritim Indonesia-Malaysia: Sebuah Retrospektif}

\begin{abstract}
Abstrak
"Good fences make good neighbor". Tetapi berapa lama waktu yang diperlukan untuk menegosiasikan pagar tersebut? Delimitasi batas negara selalu menjadi isu hangat dalam hukum dan hubungan internasional. Proses ini dapat memakan waktu bertahun-tahun. Negara-negara cenderung untuk sangat berhati-hati dalam menegosiasikan batas, karena setelah perbatasan tersebut disepakati, maka batas tersebut tidak dapat diubah.Batas maritim Indonesia dan Malaysia tidak terkecuali. Kedua negara yang relatif masih muda ini telah menegosiasikan batas maritimnya sejak tahun 1960an. Lebih dari lima puluh tahun kemudian, segmen-segmen batas maritim antar kedua negara juga belum selesai dirundingkan. Setelah sekian lama berunding, bagaimana perkembangan proses penetapan batas maritim kedua negara? Artikel ini akan mengedepankan isu-isu penting terkait dengan delimitasi batas maritim Indonesia-Malaysia, perkembangan terakhir, dan langkah kedepan yang akan ditempuh oleh kedua negara.
\end{abstract}

Kata Kunci: Delimitasi Batas Maritim , Garis Pangkal Kepulauan, Landas Kontinen, Perjanjian Perbatasan, Zona Ekonomi Eksklusif,

PADJADJARAN JOURNAL OF INTERNATIONAL LAW Volume 3 Number 1 Year 2019 [ISSN 2549-2152] [e-ISSN 2549-1296]

The Special Envoy of the Maritime Boundary Determination RI-Malaysia, Jl. Veteran No.18 Jakarta Pusat, M.A. (St. John's University, New York), eddypratomo1@gmail.com. 
Indonesia-Malaysia Maritime Boundaries Delimitation: A Retrospective

\section{A. INTRODUCTION}

Maritime boundary delimitation is a complex, multi discipline, and multi factors process. One cannot simplify the maritime delimitation as a mere negotiation that eventually leads to an agreement on where the boundary shall be drawn. There are cases in which the states concerned cannot reach an agreement and decided to bring this matter to a third-party dispute settlement mechanism. There are also events in which the government of the states concerned are not ready yet to negotiate.

The case of Indonesia and Malaysia is not an exception. Following the independence of Indonesia in 1945 and Malaysia in 1957, those states were not ready to conduct a negotiation right away. Among other things, Indonesian government was not stable yet. Military aggression from the Netherlands and internal revolution among others were the factors contributing to this unstable condition. Malaysian territory was also not affirmed yet, because Sabah and Sarawak joined the Federation at a later stage. The status of Singapore as part of the Federation (but then separated) also became a contributing factor. The land territory is important as they serve to be the baseline where the maritime zone is projected. When the land territory is not yet affirmed, then the sea boundary cannot be negotiated.

Furthermore, Indonesia and Malaysia political relations were not at a conducive stage for negotiation following the confrontation between the two countries. Practically, both Indonesia and Malaysia began to consider a maritime boundary

Malcolm N. Shaw, International Law, $7^{\text {th }}$ Edition, Cambridge: Cambridge University Press, 2014, pp. 380381.

2 See 1915 and 1928 Agreements, relevant parts mentioned in the Sovereignty over Pulau Ligitan and Pulau Sipadan (Indonesia/Malaysia), Judgement, ICJ negotiation after the end of the confrontation.

The starting point of the IndonesiaMalaysia maritime boundary delimitation is the delimitation agreement between the Netherlands and Great Britain, the predecessors of the respective states. This is based on the international law doctrine of Uti Possidetis Juris, where a new state shall have the same boundary as their predecessor colonial territory. ${ }^{1}$ Therefore, the borders between Indonesia and Malaysia will follow the one that was drawn by the Netherlands and Great Britain. However, resorting to the NetherlandsGreat Britain Agreements itself is only the starting point. These agreements only cover the land boundary in the Borneo/Kalimantan Island. 2 The Netherlands and Great Britain did not delimit the maritime boundaries which exist in the segments of the Straits of Malacca, the Celebes Sea, and two segments in the South China Sea, one off the East Coast of West Malaysia, and one off the Coast of Sarawak. Therefore, the land boundary agreements only serve as a starting point, and it is up to Indonesia and Malaysia to delimit their maritime boundaries.

Another point to consider in this matter is the development of the international law of the sea. In the early $20^{\text {th }}$ Century, the only maritime zone regime that was well established was the territorial waters. Nonetheless, the limit of the territorial waters itself are still evolving, from 3 to 12 nautical miles. ${ }^{3}$ Other maritime zones, which includes the contiguous zone, continental shelf, were still in their establishment process up until the 1958 Geneva Conventions on the Law of the Sea where it was first codified as a convention

Rep. 2002, p. 625. (Sipadan-Ligitan Case Judgment), paras. 71-73.

3 For history of the development of the territorial sea concept, see R.R. Churchill and A.V. Lowe, the Law of the Sea, $2^{\text {nd }}$ edition, 1988 , p. 59 et seq. 
provision. Until the 1958 Geneva Conventions was concluded, the maximum breadth of the territorial waters was not established, though it can be inferred that it shall not exceed beyond the contiguous zone which maximum limits was set at $12 \mathrm{NM}^{4}{ }^{4}$

Then, the archipelagic state regime, which is relevant to Indonesian baseline, began to develop through the Djuanda Declaration $1957 .{ }^{5}$ Prior to this declaration, the Indonesian maritime regime was only three nautical miles territorial sea belt around each island, regulated through the Territoriale Zee en Marietieme Kringen Ordonantie 1939. Although proclaimed one year prior to the conclusion of the Geneva Convention, the archipelagic state regime did not make it to the final text of the Geneva Convention. The archipelagic regime then eventually made it to the 1982 United Nations Convention on the Law of the Sea (UNCLOS). ${ }^{6}$ Based on UNCLOS, an archipelagic state can draw a baseline system, called the archipelagic baseline, connecting the outermost points of the outermost islands. ${ }^{7}$ The water on the inner side of the baseline is either internal waters, when it is at the landward side, or archipelagic waters when it's waters between the islands. $^{8}$

Another maritime zone that is relevant to the Indonesia-Malaysia maritime border is the Exclusive Economic Zone. ${ }^{9}$ This maritime zone basically gives sovereign rights to the coastal State for the resources within the water column up to a $200 \mathrm{~nm}$ distance from the baseline. This regime was also then regulated by UNCLOS. ${ }^{10}$

4 See The Breadth of Contiguous Zone provision, Article 24 (2), Convention on the Territorial Sea and Contiguous Zone 1958.

5 The Declaration is further elaborated and implemented by the Law No. 4/Prp. 1960 on Indonesian Waters.

6 United Nations Convention on the Law of the Sea (UNCLOS) 1982.

Article 47 of UNCLOS.

Articles 49 and 50 of UNCLOS.

For the history of the development of the Exclusive Economic Zone (EEZ) see Myron H. Nordquist (et. al.)
This article will begin with the concluded maritime boundaries between Indonesia and Malaysia. This article then will proceed with the discussion of the Sipadan-Ligitan Case, which among others contributed to the stagnation of the Indonesian delimitation negotiation. Then it will proceed with the post Sipadan-Ligitan negotiation. Further, this article will explain the current stage of the negotiation process which leads to the formation of the Special Envoy track. This article will conclude by identifying a way forward for future negotiation.

\section{B. CONCLUDED MARITIME BOUNDARIES SEGMENTS}

The early negotiation of the maritime boundaries between Indonesia and Malaysia has concluded two agreements, namely the 1969 Continental Shelves Agreement ${ }^{11}$ and 1970 Territorial Seas Treaty in the Strait of Malacca, ${ }^{12}$ and one Trilateral Agreement with Thailand.

The 1969 Agreement covered three segments of maritime boundaries, namely the Northern part of the Strait of Malacca, the Western part of the South China Sea/off the coast of West Malaysia, and the Eastern Side/off the coast of Serawak. This Agreement covered all segments where Indonesia and Malaysia have continental shelves with exception of the Celebes Sea. The negotiation on the Celebes Sea Segment was postponed due to the dispute concerning Pulau Sipadan and Pulau Ligitan.

The 1970 Treaty covers the part of the Strait of Malacca with breadth less than

(eds), UNCLOS 1982: A Commentary, Vol. II, 1993, pp. 491-510.

10 Part V, Articles 55-75, UNCLOS.

11 Agreement between the Government of Malaysia and the Government of Indonesia on the Delimitation of the Continental Shelves between the Two Countries, Kuala Lumpur, 27 October 1969.

12 Treaty between the Republic of Indonesia and Malaysia Relating to the Delimitation of the Territorial Seas of the Two Countries in the Strait of Malacca, Kuala Lumpur, 17 March 1970. 
12NM. However, this Treaty also did not cover the entire segment of the Southern part of the Strait. The southernmost part of the Strait of Malacca was yet to be delimited.

Trijunction point is also required for the most northern part of the Strait of Malacca, and this has been agreed with Thailand with the 1971 Agreement between IndonesiaMalaysia-Thailand on Continental Shelf Boundary.

Negotiation process during this time period was relatively fast. From the beginning of the negotiation process to the conclusion of the 1969 Agreement, it took less than a year. Both countries also managed to agree to set aside the Celebes Sea segment, then proceed with other segments negotiation which resulted in subsequent agreements.

Despite the fact that the continental shelf segments have already been delimited, Indonesia and Malaysia still have to delimit its EEZ boundary. As mentioned earlier, the EEZ regime was established in 1982, and that the existing agreements between Indonesia and Malaysia covers only continental shelves boundary. ${ }^{13}$

\section{THE CASE CONCERNING SOVEREIGNTY OVER SIPADAN AND LIGITAN ${ }^{14}$ AND ITS IMPLICATION}

As mentioned earlier, the negotiation of continental shelf in the Celebes Sea was postponed due to the dispute concerning the possession over Sipadan and Ligitan Islands. In fact, it was during the negotiation

\footnotetext{
13 See for example, Article I of the 1969 Agreement specifically mentioned "The boundaries of the Indonesian and Malaysian continental shelves...".

14 Sovereignty over Pulau Ligitan and Pulau Sipadan (Indonesia v. Malaysia), Judgement, ICJ Rep. 2002, p. 625. (Sipadan-Ligitan Case Judgment).

15 Sipadan-Ligitan Case Judgment, para. 135.

16 The Special Agreement was signed by Indonesia and Malaysia on 31 May 1997, then jointly submitted to the ICJ on 2 November 1998.

17 Sipadan-Ligitan Case Judgment, paras. 148-149.
}

of the continental shelf the dispute was crystalized. ${ }^{15}$ Indonesia and Malaysia discover that it has competing claims over the Islands on the East Coast of Kalimantan/Borneo when they negotiated the maritime boundary in the Celebes Sea. The negotiation then proceeded with the 1969 Agreement, leaving the Celebes Sea segment undelimited.

The settlement of the ownership dispute over the two islands was particularly important for the delimitation of the maritime boundary because of the situation of the two islands. The islands will be the outermost point of the owner's territory, where the maritime zone will be projected for the purpose of delimitation. Until this matter is resolved, delimitation cannot be proceeded.

Years of negotiation between Indonesia and Malaysia failed to reach settlement. In 1991, the two countries even established a joint working group for an in-depth negotiation but failed to reach an agreement. Both countries then designated special emissaries, and they recommended to settle the dispute through the ICJ. In 1998 , by means of a special agreement, the dispute was then submitted to the International Court of Justice (ICJ). ${ }^{16}$ The ICJ in its judgment awarded the two islands to Malaysia, as a successor of Great Britain because it was Great Britain who had exercised a continuous peaceful display of authority prior to the critical date, or the date when the dispute arose. ${ }^{17}$ After the Judgment was delivered, Indonesia adjusted its baseline system. ${ }^{18}$

18 One of the reasons why Indonesia cannot demonstrate peaceful display of sovereignty to the Islands is because the first baseline that Indonesia created as a sovereign through Law No. 4/Prp. 1960, does not listed base points in Sipadan and Ligitan which was, presumably, Indonesia's outermost point. Indonesia would then rectify this mistake through the Government Regulation No. 38/2002, but this was way after the critical date and even almost when the ICJ delivered its judgment. Indonesia further adjusted its baseline through the Government Regulation No. 37/2008 that no longer include Sipadan and Ligitan. This latest baseline system 
The ICJ award does not only have implications towards ownership and delimitation matters between the two countries. But it also creates a public stigma that Indonesian territory is prone to be "stolen" by its neighbor, as how we "lost" Sipadan-Ligitan. Although it is worth to point out that Indonesia never "lost" the Islands since it has never owned them, the first Indonesian legislation concerning its baseline did not include Sipadan-Ligitan as its base points. ${ }^{19}$

The underlying problem in this matter is that not everyone is aware of the actual case. They perceived that Sipadan and Ligitan were awarded to Malaysia because Malaysia was the one who developed the islands. The majority of Indonesian public were not aware that the ICJ only took into consideration conducts of the States prior to the critical date of 1969 . The actions done by Malaysia after 1969, despite it violated the status quo, did not count towards the final judgment.

This misperception continued when Indonesia and Malaysia proceeded after the ICJ Judgment for the delimitation, particularly in Ambalat, in the Celebes Sea. Indonesian public feared that Ambalat would be "occupied" by Malaysia.

Ambalat is the name of an oil concession block, beneath the ocean floor. It is not an island or other features that can be seen from the surface. It differs from the Sipadan-Ligitan case which concerns the territory of where the owner exercises full sovereignty, in which Ambalat mostly involves a lesser degree of rights compared to sovereignty that is called sovereign rights. In this sovereign rights area, the State only has limited authority with regard

was deposited to the United Nations Secretary General, in accordance with the obligation under Article 47 (9) of UNCLOS.

19 See Law No. 4/Prp. 1960 on Indonesian Waters.

20 The media also highlighted that there is a territorial intrusion in Ambalat. But whether or not there is a territorial intrusion, it depends on a number of conditions. If the said ship passes within the territorial to the exploration of its natural resources. ${ }^{20}$ Moving forward, negotiating maritime boundaries with Malaysia will cause the burden on how to clarify the public misperception, however the mutually agreed result will not be perceived with negative sentiments.

\section{CHALLENGES TO CONCLUDE MARITIME BOUNDARY: MEDIAN LINE AND EQUITABLE SOLUTION}

The task of the maritime delimitation is simple, but it is difficult to be fulfilled. The task is only to draw an agreed line for delimitation. However, in order to draw the agreed line for both states to be accepted is very difficult. It is certain that every state wants to have its maximum claim, but they often forget that there is the interest of the other state in the same area. Resorting only to the principles of international law as depicted in the UNCLOS is not enough, but it is an important starting point that will guide the entire delimitation process.

For the territorial waters delimitation regarding to the guiding principle in the UNCLOS, unless otherwise agreed by the parties, is the median line between the baselines. ${ }^{21}$ However, during the negotiation it is often found that one party does not agree on the other party method of drawing the baseline. In regards to the Indonesia and Malaysia case, although both are parties to the UNCLOS, different interpretations of the UNCLOS provision resulted in disagreement of viewing each other's baseline. Malaysia is of the opinion that Indonesia shall not use the archipelagic baseline to calculate the median line, while Malaysia itself exercised the straight

waters claim and it exercises more than what is allowed in the innocent passage scheme, then there is a violation. If the said ship passes outside the territorial waters claim of Ambalat, then there is a violation only if the said ship engages in exploration or exploitation of the marine resources.

21 See Article 15 of UNCLOS. 
baseline where there was no fringe of islands in the immediate coastline nor a deeply indented or cut into coastline. ${ }^{22}$

Moving forward to other maritime zones, namely the Economic Exclusive Zone (EEZ) and the continental shelf, the basic principle contained in UNCLOS is even broader, which stated that delimitation is aimed to achieve an equitable solution. ${ }^{23}$ International courts and tribunal have also upheld this principle, as early as 1969 before UNCLOS in the North Sea Continental Shelf Case. ${ }^{24}$ However, the term "equitable" was not explained further in UNCLOS, courts and tribunal tend to assess it on a case by case basis in order to set a clear parameter. Furthermore, there is no clear list of what can be considered as relevant circumstances and what factors are irrelevant. However, international courts and tribunal in all delimitation cases considered geographic factors of the delimitation area such as configuration of the coastline, ${ }^{25}$ the length of relevant coastline, ${ }^{26}$ presence of maritime features, ${ }^{27}$ and proportionality, as the most relevant factors. ${ }^{28}$

\footnotetext{
22 For methods of drawing archipelagic baseline and straight baseline, see Articles 7 and 47, UNCLOS.

23 See Article 74 and 83 of UNCLOS.

24 The North Sea Continental Shelf Case (Germany v. Denmark; Germany v. the Netherlands), judgement, ICJ Rep. 1969, p. 3, para. 101: the ICJ stipulated that, "delimitation is to be affected by agreement in accordance with equitable principles, and taking account of all the relevant circumstances ".

25 See the North Sea Continental Shelf Case, Judgment, para. 101. The full stipulation of the ICJ on this matter is that the ICJ requires the coastal States to negotiate and take into consideration:

1. the general configuration of the coast

2. the physical and geological structure and natural resources of the continental shelf;

$3 . \quad$ proportionality.

This judgment then often referred to by subsequent judgment on maritime delimitation.
}

\section{E. CHALLENGES TO CONCLUDE MARITIME BOUNDARY: PROJECTION OF MARITIME ZONE, BASE POINTS AND BASELINE}

Particular regard was given to the presence of maritime features. Different types of maritime features entitles different treatment and different maritime zones that they can project. In general, UNCLOS sets three categorization of these features, namely low tide elevation, rock, and island. UNCLOS defines low tide elevation as a land that is above water on low tide but submerged on high tide, whereas it can only generate a maritime zone if it was located within the territorial waters of the mainland or other maritime zone. ${ }^{29}$ UNCLOS then defined islands and rocks as a land surrounded by water that is above water on high tide. The difference between the two, as UNCLOS further stipulated, is that rocks which cannot sustain human habitation or economic life of their own shall have no EEZ or continental shelf of their own. ${ }^{30}$

The difference between these maritime features in reality is not as clear as what the UNCLOS prescribes. In some cases, states will find disagreement whether to classify a feature as a rock or a low tide elevation. Moreover in negotiation, sometimes it is difficult to agree whether a feature is a low tide elevation or a complete submerge

\footnotetext{
26 See also the Land and Maritime Boundary between Cameroon and Nigeria (Cameroon v. Nigeria: Equatorial Guinea intervening), Judgment, ICJ Rep. 2002, p. 442, para. 90; the Territorial and Maritime Dispute between Nicaragua and Honduras in the Caribbean Sea (Nicaragua v. Honduras), Judgment, ICJ Rep. 2007, p. 659, para. 289.

27 See, for example, the Maritime Delimitation and Territorial Questions between Qatar and Bahrain (Qatar v. Bahrain), Judgment, ICJ. Rep. 2001, p. 94, paras. 218-220. 28 See, for example, the Dispute concerning Delimitation of the Maritime Boundary between Bangladesh and Myanmar/Case No. 16 (Bangladesh v. Myanmar), Judgment, ITLOS 2012, para. 499, where the ITLOS applies the disproportionality test.

29 Article 13, UNCLOS. A low tide elevation itself is not susceptible for ownership or occupation if it's not part of a mainland or other maritime features.

30 See Article 121 of UNCLOS.
} 
feature because the high-tide and low-tide frequency in certain areas can take a very long time. Further, the parameter of "[to] sustain human habitation or economic life of their own" is also not elaborated clearly in UNCLOS to differentiate between rocks and islands.

In most cases, courts and tribunal did not spend to discuss whether a feature is classified as a rock or island and caught in the terminology, but rather went straight to the effect of the maritime features to the delimitation line. The court would determine whether the feature are given full effect, ${ }^{31}$ half effect or partial effect, ${ }^{32}$ or even no effect towards the delimitation. ${ }^{33}$

In negotiating maritime boundary with Malaysia, the classification of the maritime feature, on where to place the base point, whether it can be drawn from a particular maritime feature and how to employ the baseline, as well as the projection of maritime zone from the mainland and the maritime features, needs to be agreed upon by Indonesia and Malaysia. Further, both states have to agree on the effect of the maritime features to project the maritime zones, whether it can have full effect, partial effect, or even no effect.

\section{F. INTERPRETATION ON LEGAL AND TECHNICAL ASPECTS ON THE INDONESIA-MALAYSIA MARITIME DELIMITATION}

In relation with the theoretical challenges that have been elaborated in the two proceeding's sections, Indonesia and Malaysia still have two basic differences to settle. The first is regarding the drawing of the baseline and the second is about the EEZ delimitation.

Regarding the baseline of the respective countries, Malaysia employed a method of a straight baseline system when it was not supposed to. Malaysia as a coastal State may only draw a straight baseline in the localities where the coastline is deeply indented or cut into, or if there is a fringe of islands along the coastline. ${ }^{34}$ Although Malaysia is yet to publish its baseline, the 1979 map of Malaysia shows that Malaysia are using a straight baseline system to project its maritime zones even when there are no geographical conditions to justify it. ${ }^{35}$

In the Southernmost part of the Strait of Malacca, the claim of Malaysia's territorial waters even cut through Indonesian archipelagic baseline. As mentioned earlier, baseline is the starting point of maritime zone projection, thus cutting Indonesian baseline demonstrated that Malaysia did not acknowledge the existence of Indonesian territorial waters projected by the baseline, in which the boundaries are still subject to negotiation. This 1979 map

the delimitation line shall be adjusted closer to the Malta side, thus, the Island of Malta only have partial effect in the delimitation when it delimit with the mainland of Libya.

33 See Award of the Arbitral Tribunal in the Second Stage of the Proceeding (Eritrea v. Yemen), Reports International Arbitral Award vol. XXII 17 December 199, p. 335, para. 148.

34 See Article 7 of UNCLOS.

35 See the Map that was published on 21 December 1979 titled "Peta Baru Menunjukan Sempadan Perairan dan Pelantar Benua Malaysia" (New Map Showing the Territorial Waters and Continental Shelf Boundaries of Malaysia). 
was protested by Indonesia and other neighboring States, including Singapore.

Malaysia's unilateral claim in cutting Indonesian baseline shows that it does not acknowledge Indonesia as an archipelagic State. Indonesian archipelagic baseline on the other hand has already been drawn in accordance with UNCLOS. ${ }^{36}$ Indonesia's geographical characteristic justifies it to become an archipelagic state and to draw an archipelagic baseline. The archipelagic baseline of Indonesia has never been protested by other States, and even received acknowledgement that it is already drawn in accordance with UNCLOS. ${ }^{37}$ Moreover, Malaysia has also specifically acknowledged Indonesia as an archipelagic State in the 1982 Agreement. ${ }^{38}$ Thus, Malaysia is supposed to accept the existence of Indonesian baseline.

Secondly, Malaysia insists on a single line for both Exclusive Economic Zone (EEZ) and continental shelf boundary, while Indonesia's position of EEZ boundary is yet to be negotiated and delimited by the two countries. 39 As mentioned earlier, Indonesia and Malaysia have concluded continental shelf agreements before the EEZ regime was adopted in international law. Further, the agreements were specifically mentioned for a seabed jurisdiction, and not anticipating or indicating that the agreed line will also be applicable as a water column jurisdiction vis $a$ vis EEZ. Thus, Indonesia and Malaysia are yet to agree on an EEZ boundary.

36 See Article 47 of UNCLOS

37 United States Department of State Bureau of Oceans and International Environmental and Scientific Affairs, Limits in the Sea No. 141 Indonesia: Archipelagic and other Maritime Claims and Boundaries, 15 September 2014, p. 3.

38 Treaty between the Republic of Indonesia and Malaysia relating to the Legal Regime of Archipelagic State and the Rights of Malaysia in the Territorial Sea and Archipelagic Waters as well as in the Airspace Above the Territorial Sea, Archipelagic Waters and the Territory of the Republic of Indonesia Lying between East and West Malaysia, 25 February 1982.

\section{G. CURRENT STAGE OF NEGOTIATION}

In 2004, the Ministry of Foreign Affairs of Indonesia enacted a decree to establish the Technical Team for Maritime Boundaries Delimitation. This Technical Team is the new negotiating team between Indonesia and its neighbors, including Malaysia. The first meeting of the Technical Team between Indonesia and Malaysia was in 2005, and the latest one was in June 2015. For around ten years, Indonesia and Malaysia have conducted 28 rounds of negotiation. During these rounds of negotiation, the two negotiating teams exercised a possible boundary line, guided by the principles of international law as prescribed in UNCLOS and decisions of international courts and tribunals. Segments that are to be delimited are the Celebes Sea (territorial sea, EEZ and continental shelf), the South China Sea (in the vicinity of Tanjung Datu for territorial sea, and EEZ), Eastern Part of the Singapore Strait (territorial sea) ${ }^{40}$ the Southernmost Part of the Strait of Malacca (territorial sea), and the Strait of Malacca (EEZ).

In almost ten years' time period since the starting of the negotiation, Indonesia and Malaysia have not concluded any single maritime boundary in any of the remaining segments. This is in stark contrast compared to the early negotiation with Malaysia before the Sipadan-Ligitan dispute. Additionally, in the same period of time Indonesia has concluded maritime

39 For Malaysian perspective, see B.A. Hamzah et.al., "The Maritime Boundaries of Malaysia and Indonesia in the Malacca Strait: an Appraisal," Australian Journal of Maritime and Oceans Affairs, Vol. 6 No.4, 2014, pp. 207226.

40 In this area, the negotiation was also being postponed due to the dispute between Malaysia and Singapore over the ownership of Pedra Branca, South Ledge, and Middle Rock. This dispute was then settled through the ICJ, see Sovereignty over Pedra Branca/ Pulau Batu Puteh, Middle Rocks and South Ledge (Malaysia v. Singapore), Judgment, ICJ Rep. 2008, p. 12. 
boundary agreement with the Philippines, and two agreements with Singapore.

It is also understandable that Malaysia is not dealing only with Indonesia in its maritime boundary issues. In 2003, Malaysia and Singapore submitted their dispute over sovereignty of Pedra Branca, Middle Rocks, and South Ledge to the ICJ. During the proceeding of the case, Malaysia's attention was also focused to win this case. The ICJ then issued its judgment in 2008, deciding that Pedra Branca belonged to Singapore, Middle Rocks belonged to Malaysia, and South Ledge belonged to the country whose territorial sea covers South Ledge after they delimited the maritime zones. It can be inferred that the ICJ judgment was not predicted by either Singapore or Malaysia, and it even leaves a burdensome homework with regard to the status of South Ledge and the delimitation in the area. Furthermore, the delimitation will also affect Indonesia and at some points it will become a tripartite negotiation.

Negotiating boundaries between Indonesia and Malaysia under the current domestic situation in Indonesia will be very delicate. On one hand, Indonesian public is still traumatized with the past decision of the ICJ on Sipadan-Ligitan and felt that it lost the Islands and now facing the possibilities of losing Ambalat. On the other hand, Malaysia lost Pedra Branca to Singapore, ${ }^{41}$ to some extent it also affects the domestic views of Malaysia not to go to ICJ in the near future. Although it is unlikely that Indonesia and Malaysia will settle the delimitation case to a third party, the two countries felt the urgency to settle their borders in the near future.

Following the long period of negotiation with no tangible results, in February 2015, the Indonesian President and the Malaysian

41 The case of Pedra Branca is different from SipadanLigitan. While Sipadan-Ligitan at one point was considered as no man's land or terra nullius, Pedra
Prime Minister agreed that each country would designate a special envoy to expedite the delimitation of the maritime boundaries. The initiative to designate special envoys was initially discussed during President Susilo Bambang Yudhoyono's administration, then continued to President Joko Widodo's administration. This establishment of a special envoy track, although looks similar with the one created in 1991, is actually different. The mandate of the special envoys is beyond the legal and technical aspect mandate that is given to the Technical Team.

The special envoys also have the mandate to explore other options that take into account political, economic, defense, and security aspects. The special envoys will take up the latest development made by the Technical Teams of both countries and explore creative solutions for the agreed line.

\section{H. CONCLUSION}

From the historical point of view it can be inferred that post 1970's, the delimitation between Indonesia and Malaysia proceeded with high degree of caution. The main consideration of why negotiating a maritime boundary has to be taken with a high degree of caution is because once it is settled the boundary cannot be changed unless with agreement of both states. Unlike other types of international agreement whereas a party can terminate or withdraw from it based on a fundamental change of circumstances, the Vienna Convention on the Law of Treaties stipulated that if a treaty establishes a boundary then fundamental change of circumstances cannot be invoked to be withdrawn or terminated from the treaty. ${ }^{42}$ Although in this regard only Malaysia is a

Branca belonged to Johor (Malaysia) until the title was transferred to Singapore, see Judgment para. 276.

42 See Article 62, Vienna Convention on the Law of Treaties 1969. 
Indonesia-Malaysia Maritime Boundaries Delimitation: A Retrospective

party to the Convention, ${ }^{43}$ This principle is a customary international law that also binds Indonesia. ${ }^{44}$ Rather than rushing for a final delimitation then regret it at a later stage, Indonesia and Malaysia preferred to proceed with serious caution.

Distortion of information to the public also needs to be clarified. Indonesian public has to understand that the past experience with the ICJ judgment on Sipadan-Ligitan was not a taboo for its sovereignty. And the overreacting paranoia will not benefit the country's development. It is important for both the public in Indonesia as well as in Malaysia to understand the context of maritime delimitation and view the negotiation process objectively.

Post-ICJ experience, in which both Indonesia and Malaysia have experienced losing a case, it is unlikely that both states are ready to go back to a binding third party dispute settlement. The Special Envoy track would be a new avenue for both countries to settle their maritime delimitation, with the process still on bilateral level which they have full control over the result of the delimitation. This is the advantage of a negotiated solution, whereas third party settlement results sometimes are difficult to predict and it might not be acceptable for both Indonesia and Malaysia. Further, the unpredictability of the result of a third-party binding dispute settlement mechanism is also a factor that influences the decision of both states to settle their delimitation on a bilateral level.

Not less important is the acknowledgement of the fact that the negotiation process is aimed to reach a mutually agreed solution. Therefore, it is impossible to have the negotiated result the same with the maximum claim that was

43 See United Nations, "Status of the Vienna Convention on the Law of Treaties", UN Treaties Series, https://treaties.un.org/pages/ViewDetails/ll.aspx?src= TREATY\&mtdsg_no $=X X I I I-$

$1 \&$ chapter $=23 \&$ Temp $=m$ tdsg3\&lang $=e n$, last accessed 28 August 2015. initially introduced by the states. Having a negotiation would mean that both states' positions would have to meet in the middle and reach a package deal for all of its interests.

The newly established Special Envoy track is hoped to bring fresh ideas and breakthroughs to the delimitation process. The expanded mandates of the special envoys are expected to consider multiple factors beyond the technical consideration of delimitation, in order to obtain equitable solutions for both countries. It is hoped that, without being limited to legal and technical options for delimitation, the Special Envoy track would come up with a recommendation that can be acceptable for both Indonesia and Malaysia.

\section{REFERENCES}

\section{Books}

Churchill, R.R. and A.V. Lowe, the Law of the Sea, $2^{\text {nd }}$ edition, Manchester University Press, Manchester, 1988.

Nordquist, Myron H. (et. al.) (eds), UNCLOS 1982: A Commentary, Vol. II, Martinus Nijhoff Publisher, Dordrecht, 1993.

Shaw, Malcolm N., International Law, $7^{\text {th }}$ Edition, Cambridge University Press, Cambridge, 2014.

\section{Other Documents}

B. A. Hamzah (et.al.), "The Maritime Boundaries of Malaysia and Indonesia in the Malacca Strait: an Appraisal", Australian Journal of Maritime and Oceans Affairs, Volume 6, Issue 4, 2014.

United Nations, "Status of the Vienna Convention on the Law of Treaties", UN Treaties Series, https://treaties.un.org/pages/ViewDeta

44 The principles embodied in Article 62 of the Vienna Convention on the Law of Treaties have been regarded as a codification of customary law, see Fisheries Jurisdiction Case (United Kingdom v. Island), Jurisdiction of the Court, Judgment, ICJ Rep. 1973, p.3, para. 36; see also Gabcikovo Nagymaros Project Case (Hungary v. Slovakia), Judgment, ICJ Rep. 1997, p. 7, para. 46. 
ilsIII.aspx?src $=$ TREATY\&mtdsg_no $=X X I I I-$ 1 \& chapter $=23 \&$ Temp $=m t d s g 3$ \&lang $=e n$ , last accessed 28 August 2015.

United States Department of State Bureau of Oceans and International Environmental and Scientific Affairs, Limits in the Sea No. 141 Indonesia: Archipelagic and other Maritime Claims and Boundaries, 15 September 2014.

\section{Legal Documents}

Agreement between the Government of Malaysia and the Government of Indonesia on the Delimitation of the Continental Shelves between the Two Countries, Kuala Lumpur, 27 October 1969.

Award of the Arbitral Tribunal in the Second Stage of the Proceeding (Eritrea v. Yemen), Reports International Arbitral Award, Vol. XXII 17 December 1999.

Continental Shelf Case (Libya v. Malta), Judgment, ICJ Rep. 1985.

Convention on the Territorial Sea and Contiguous Zone 1958.

Dispute concerning Delimitation of the Maritime Boundary between Bangladesh and Myanmar/ Case No. 16 (Bangladesh/Myanmar), Judgment, ITLOS 2012.

Fisheries Jurisdiction Case (United Kingdom v. Island), Jurisdiction of the Court, Judgment, ICJ Rep. 1973.

Gabcikovo Nagymaros Project Case (Hungary v. Slovakia), Judgment, ICJ Rep. 1997.

Indonesian Law No. 4/Prp. 1960 on Indonesian Waters (Undang-Undang No. 4/Prp. Tahun 1960 tentang Perairan Indonesia).

Indonesian Government Regulation No. $38 / 2002$ on the list of coordinate of points of Indonesian Archipelagic Baseline (Peraturan Pemerintah No. 38/2002 tentang Daftar Koordinat Geografis Titik-Titik Garis Pangkal Kepulauan Indonesia).
Indonesian Government Regulation No. $37 / 2008$ on amendment of Government Regulation No. 38/2002 on the list of coordinate of points of Indonesian Archipelagic Baseline (Peraturan Pemerintah No. 37/2008 tentang Perubahan atas Peraturan Pemerintah No. 38/2002 tentang Daftar Koordinat Geografis Titik-Titik Garis Pangkal Kepulauan Indonesia).

Land and Maritime Boundary between Cameroon and Nigeria (Cameroon v. Nigeria: Equatorial Guinea intervening), Judgment, ICJ Rep. 2002.

Maritime Delimitation and Territorial Questions between Qatar and Bahrain (Qatar v. Bahrain), Judgment, ICJ. Rep. 2001.

North Sea Continental Shelf Case (Germany v. Denmark; Germany v. the Netherlands), judgement, ICJ Rep. 1969.

Sovereignty over Pulau Ligitan and Pulau Sipadan (Indonesia/Malaysia), Judgement, ICJ Rep. 2002, p. 625.

Territorial and Maritime Dispute between Nicaragua and Honduras in the Caribbean Sea (Nicaragua v. Honduras), Judgment, ICJ Rep. 2007.

Treaty between the Republic of Indonesia and Malaysia Relating to the Delimitation of the Territorial Seas of the Two Countries in the Strait of Malacca, Kuala Lumpur, 17 March 1970.

Treaty between the Republic of Indonesia and Malaysia relating to the Legal Regime of Archipelagic State and the Rights of Malaysia in the Territorial Sea and Archipelagic Waters as well as in the Airspace Above the Territorial Sea, Archipelagic Waters and the Territory of the Republic of the Republic of Indonesia Lying between East and West Malaysia, 25 February 1982.

United Nations Convention on the Law of the Sea 1982.

Vienna Convention on the Law of Treaties 1969. 